\title{
FORMA URBANA E ESPAÇOS LIVRES \\ NA CIDADE DE UBERLÂNDIA (MG), BRASIL
}

\author{
URBAN FORM AND OPEN SPACES IN UBERLÂNDIA (MG), BRASIL
}

\author{
Glauco de Paula Cocozza* \\ Lucas Martins de Oliveira**
}

\begin{abstract}
RESUMO
Este trabalho apresenta parte da pesquisa Forma urbana e espaços livres na cidade de Uberlândia, MG, que visa à compreensão de como os espaços livres se caracterizam na cidade e como são estruturantes da sua forma urbana. Para isto, fez-se necessário um resgate histórico da evolução da forma urbana, através de fontes secundárias e primárias, desde sua aglomeração inicial, relativamente recente, em meados de 1850, até os dias atuais. Sendo assim, foi possível entender os determinantes econômicos, políticos, sociais, físicos e legais que a moldaram, os conflitos sociais e ambientais enfrentados, as influências urbanísticas vigentes em cada período, bem como perceber os desafios e as potencialidades urbanas atualmente existentes. Pretende-se contribuir e aprofundar os conhecimentos sobre como os espaços livres estruturam a forma urbana das cidades médias brasileiras, tendo como objeto de estudo a cidade de Uberlândia, ampliando a discussão do seu papel na conformação de cidades com maior qualidade urbana e ambiental.

Palavras-chave: Forma urbana. Espaços livres. Espaços públicos. Cidade média. Transformação urbana.
\end{abstract}

\begin{abstract}
This paper presents part of the research project Urban form and open spaces in the city of Uberlandia, MG. The research aims to understand how open spaces are characterized in the city and how they are structuring their urban form. For this, it was necessary a historical evolution of urban form through secondary and primary sources, since it's relatively recent start crowding in mid-1850 to the present day. Therefore, it was possible to understand the economic, political, social, physical and legal determinants that shaped the urban form, the social and environmental conflicts, the urban influences prevailing in each period, as well as understand the challenges and potential urban areas that currently exist. It is intended to contribute and deepen the knowledge about how the open space structure the urban form of medium-sized Brazilian cities, with the object of study Uberlândia, extending the discussion of their role in shaping cities with urban and environmental greatest quality.
\end{abstract}

Keywords: Urban form. Open spaces. Medium-sized city. Urban transformation. Public spaces.

* Professor adjunto da Faculdade de Arquitetura e Urbanismo e Design da Universidade Federal de Uberlândia (FAUeD/UFU).

glauco_cocozza@yahoo.com.br

** Pesquisador - Programa Institucional de Apoio à Iniciação Científica (PIAIC) - Faculdade de Arquitetura e Urbanismo e Design da Universidade Federal de Uberlândia (FAUeD/UFU).

Imdeoliveira@gmail.com 


\section{INTRODUÇÃO}

Os estudos da forma urbana revelam diferentes modos de analisar o tecido urbano, convergindo para considerações que focam determinados elementos de investigação, geralmente demonstrando aspectos essenciais para um objetivo específico. Os espaços livres estão distribuídos de diferentes formas pelo tecido urbano, diferenciando-se em categorias, áreas, forma, usos, gestão, significados e apropriação. Analisar as formas urbanas através dos espaços livres significa compreender como a formação das mesmas incorporou esta categoria de espaço em seu desenho, convergindo para diferentes tipos de parcelamentos.

A sua inserção como um dos principais elementos definidores da estrutura morfológica das cidades médias possibilitou uma melhor identificação dos setores urbanos definidos por Amorim e Sena (2005) como estruturantes da forma urbana de uma cidade média: o centro e subcentro, o pericentro e a periferia, além dos parcelamentos dispersos existentes na região periférica. Esta estrutura define não somente como os espaços livres se distribuem, mas como este sistema é capaz de organizar o tecido urbano em diferentes níveis, seja na condição física do espaço como na esfera pública em diferentes tipos de espaços.

Os espaços livres em cidades médias do interior do Brasil apresentam padrões morfológicos próprios e que se diferenciam conforme a região, a população, as características geográficas e econômicas. Porém, pode-se dizer que um modelo se repete, formado por um conjunto que geralmente se caracteriza por praças centrais originárias do adro religioso, dos espaços cívicos e da prática mercantil; praças, avenidas arborizadas e, em alguns casos, parques em bairros pericentrais que apresentam boa qualidade espacial; e uma região periférica, tomada por loteamentos com baixa qualidade espacial - em contraste com os condomínios fechados pontuais, que simbolizam a perda da urbanidade em muitas cidades brasileiras.

Uberlândia se encaixa no modelo acima descrito, e o que se observa neste artigo sintetiza as transformações que a cidade teve até chegar à sua forma atual, evidenciando como o poder econômico, as decisões políticas e a legislação urbana e ambiental determinaram os padrões urbanísticos de cada época. Assim como as metrópoles e as pequenas cidades, as cidades médias estão redefinindo o seu papel perante a estrutura urbana brasileira, tendo importante papel econômico regional, que transforma cada vez mais o seu espaço e a sua paisagem urbana.

Uberlândia é a segunda maior cidade em população do Estado de Minas Gerais, com 611.903 habitantes, segundo o Instituto Brasileiro de Geografia e Estatística (IBGE), e possui alto Índice de Desenvolvimento Humano (IDH). Tem, na prestação de serviços e na agroindústria sua base econômica, que fez com que se destacasse como uma das principais cidades do interior brasileiro. Nos últimos anos, o grande incentivo do governo brasileiro para a construção civil, como o programa de moradia Minha Casa Minha Vida, acelerou a transformação da paisagem da cidade, intervindo no conjunto 
urbano com parcelamentos de pouca qualidade espacial e ambiental, resenhando as áreas periféricas da cidade.

A figura 1 apresenta uma adaptação do modelo de cidade média proposto por Amorim e Sena (2005), na qual identificamos as zonas definidas por eles e que definem a forma urbana de uma cidade média, incorporando alguns elementos do sistema de espaços livres como essenciais no entendimento da configuração morfológica e estrutural das cidades médias brasileiras.

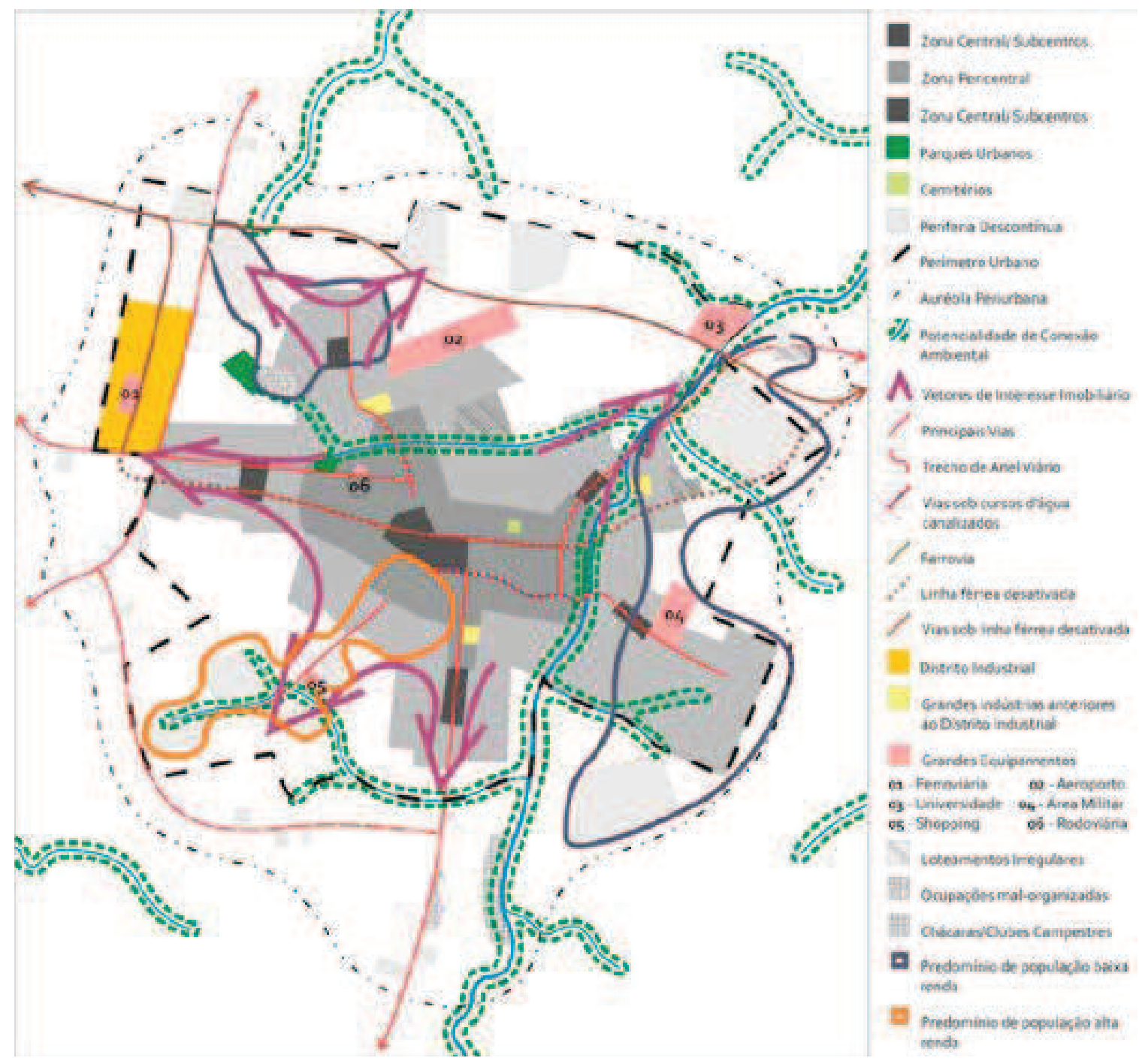

Figura 1 Revisão do modelo morfológico das cidades médias brasileiras feita por Amorim e Sena (2005), incorporando os espaços livres como elementos estruturais da forma urbana. Fonte: Cocozza e Oliveira $(2011$, p. 6).

Ao crescer rapidamente, e pautada por uma visão desenvolvimentista do seu espaço, a cidade, por muitos anos, negligenciou parte deste potencial "paisagístico" que poderia determinar um novo contexto urbano-ambiental. Este estudo permite que possamos entender esta configuração ao longo do tempo, e visualizar quais decisões - políticas, técnicas ou econômicas - configuraram o atual conjunto de espaços livres que determinam a sua forma. 


\section{A EXPANSÃO DA FORMA URBANA EM UBERLÂNDIA}

Este item apresenta os períodos que caracterizam a transformação da forma urbana em Uberlândia, apresentando os contextos políticos, socioeconômicos, a legislação ambiental e urbana e os padrões urbanísticos que definiram o desenho e o papel dos espaços livres na forma urbana.

\subsection{DA FUNDAÇÃO A 1920: A ECONOMIA RURAL E A CHEGADA DA FERROVIA}

O desenho inicial da cidade de Uberlândia, denominada, em 1852, São Pedro de Uberabinha, seguia os modelos de ocupação da região conhecida como Sertão da Farinha Podre, conhecida atualmente como Triângulo Mineiro. Esta ocupação determinava os novos núcleos urbanos, com a igreja católica sendo a principal construção da cidade próxima a cursos d'água, seguida por adros, na frente e atrás desta construção religiosa, e construções ao redor dos espaços livres que distribuíam pelo tecido urbano.

O espaço livre apresentava importante função na estruturação da cidade, tendo atribuições distintas - adro religioso, comércio, parada de tropas, cemitério - e definindo os modos de vida da população da época. A implantação da cidade deu-se pela orientação da igreja matriz, de frente ao córrego São Pedro, organizando o núcleo urbano inicial. Um primeiro instante de crescimento ocorreu junto aos caminhos para cidades próximas - Uberaba, Araguari - e junto a outros espaços religiosos, como a igreja do Rosário, em setor oposto à igreja principal, destinada à população negra da cidade, com o seu adro definindo outro importante espaço livre deste núcleo.

Comparada a outras cidades do Triângulo Mineiro, Uberlândia era uma das menos desenvolvidas, apresentando poucas igrejas e poucas edificações relevantes, porém, este aspecto do seu desenho tornou-se um importante elemento do espaço urbano, e o conjunto de espaços livres desta época é, na atualidade, uma das principais qualidades do bairro Fundinho.

Após este crescimento sem "aparente ordenamento", até 1895, a cidade expandiu-se em direção à estação ferroviária, em um traçado urbano elaborado pela própria empresa Ferrovia Mogiana - que havia ultrapassado o território paulista, cruzado a região do Triângulo Mineiro e almejava alcançar o Estado de Goiás (figura 2).

Neste período, a cidade consolida-se em duas regiões morfológicas distintas: primeiro núcleo, atual bairro Fundinho, com traçado mais irregular, e a parte alta, atual Centro, com traçado ortogonal. Os limites físicos da cidade nesta época eram os córregos da bacia do rio Uberabinha, ao sul, e a Ferrovia Mogiana ao norte (figura 3). A configuração dos espaços livres, que antes eram originados a partir de espaços de caráter utilitário, configura-se na parte alta do plano, a partir do desenho ortogonal, onde o espaço da praça é uma quadra sem ocupação, sendo o mais significativo dos espaços livres desta época a praça dos Bambus, atual praça Tubal Vilela. 


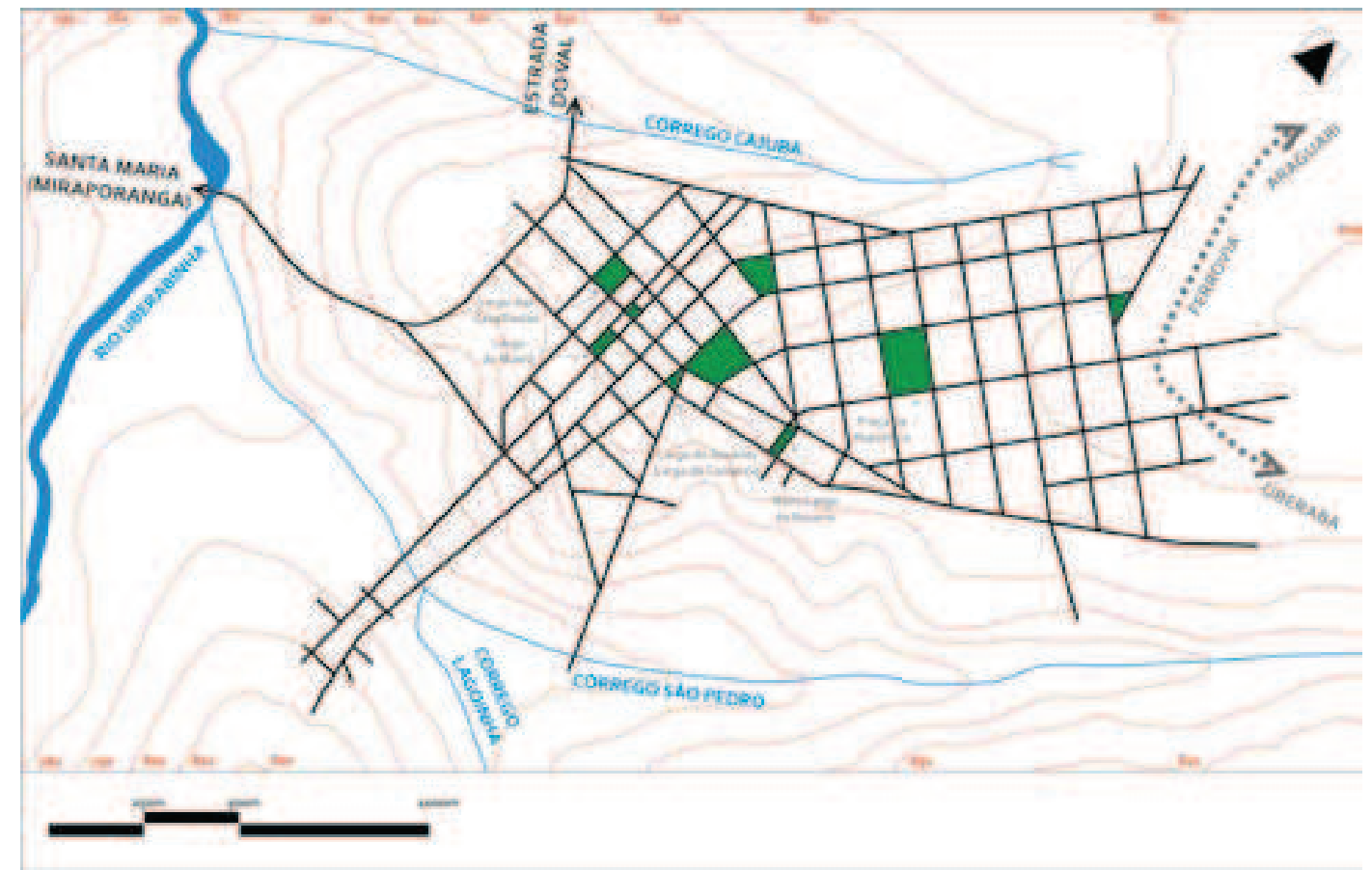

Figura 2 Trama urbana de Uberlândia em 1920, ressaltando os espaços livres. Fonte: Cocozza e Oliveira (2011, p. 10).

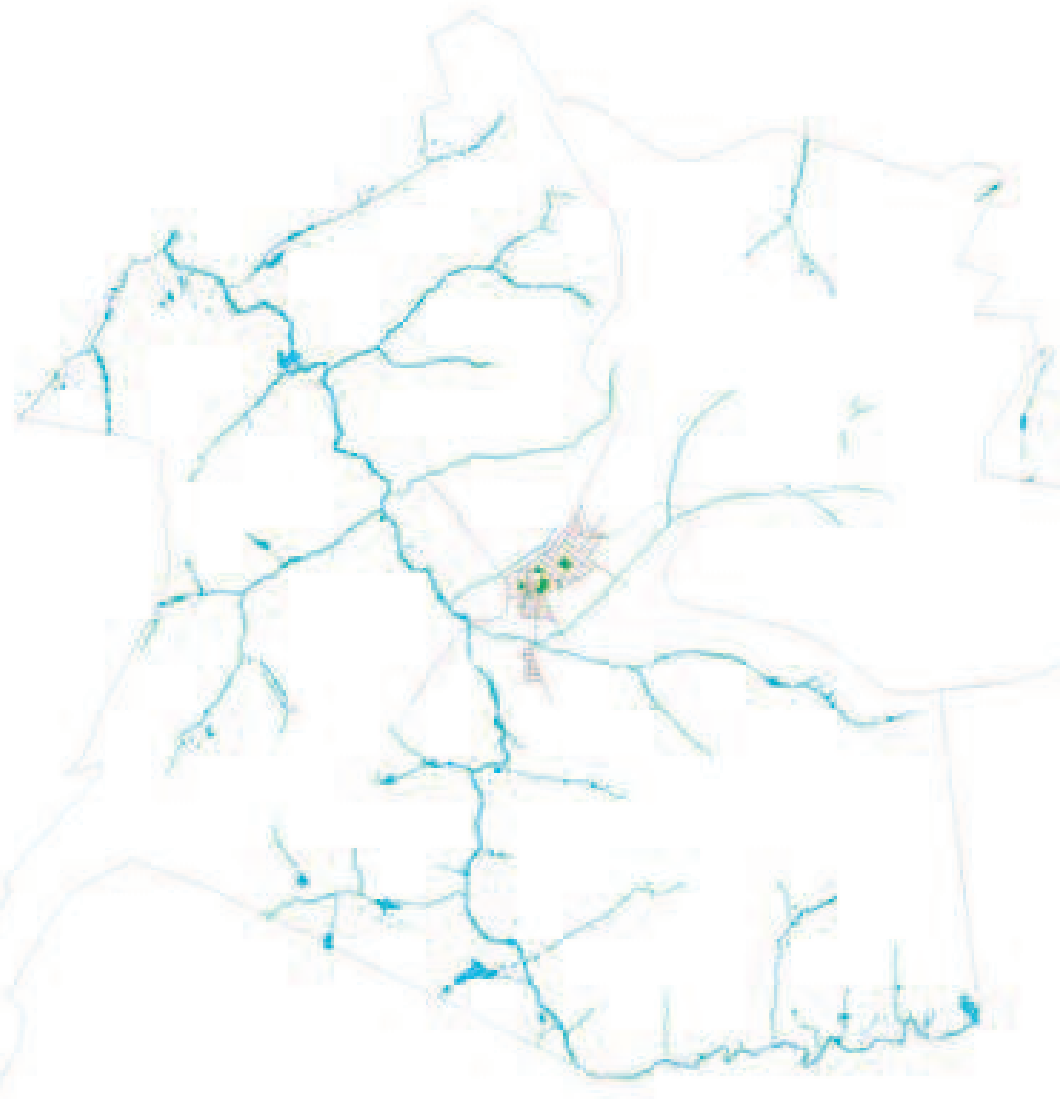

Figura 3 Forma urbana de Uberlândia em 1920.

Adaptação e elaboração: Glauco de Paula Cocozza e Lucas Martins de Oliveira.

Fonte do mapa base: Prefeitura Municipal de Uberlândia. 
Atualmente, ela é a principal centralidade de Uberlândia, ponto de manifestações, festas, ponto de encontro de parte da população. Seu desenho sofreu três importantes transformações, sendo a mais expressiva o projeto do arquiteto Jorge Cury, em 1962' (figura 4). A estrutura inicial definiu um sistema de praças no bairro histórico que se conectava com a parte alta, definindo a qualidade da sua estrutura urbana. Essa organização definiu o padrão morfológico da área, caracterizou a região central da cidade e promoveu diferentes tipos de apropriação no espaço público.

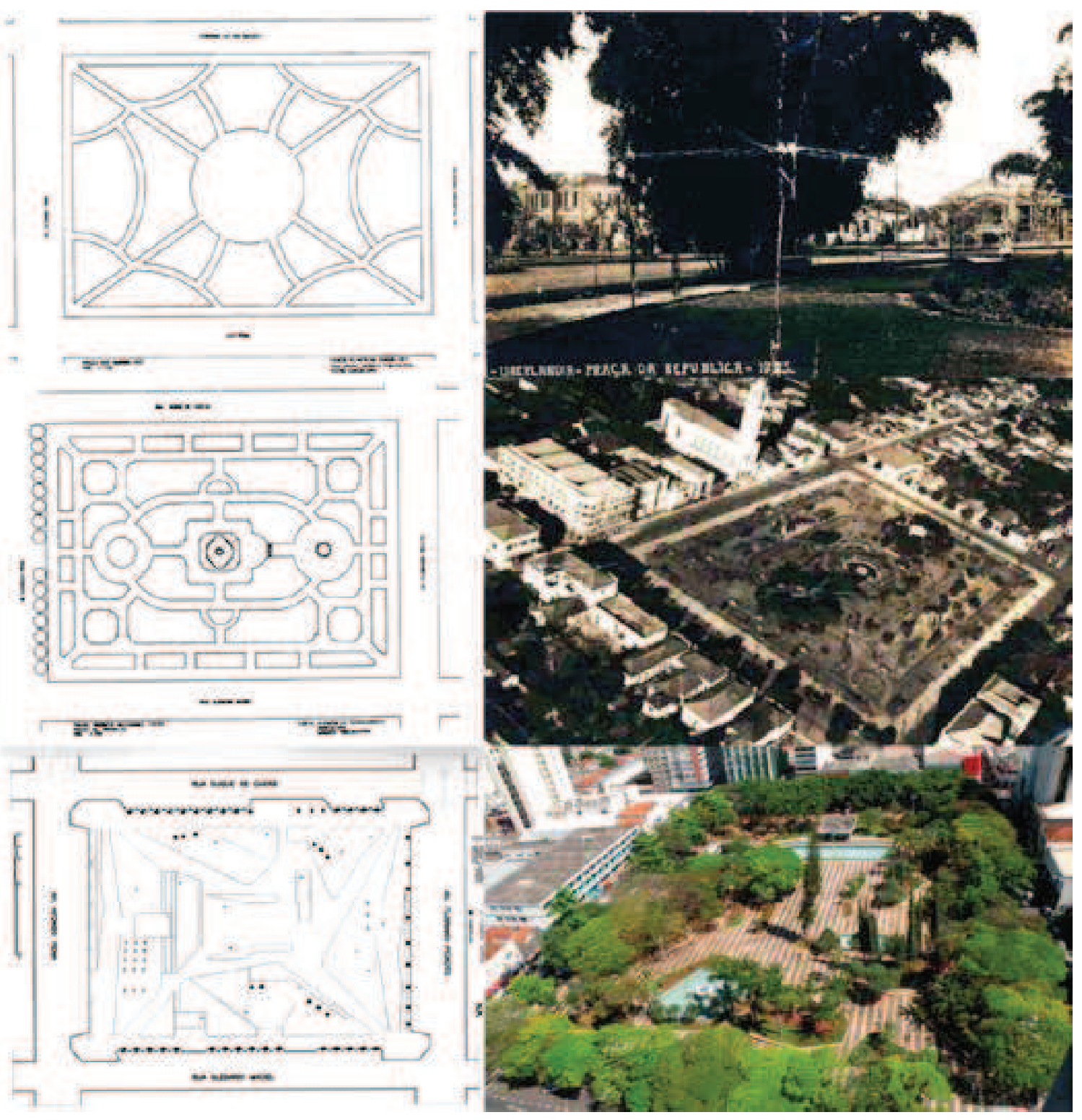

Figura 4 Praça Tubal Vilela. Até 1938 - Primeiro desenho para a então praça da República (popularmente chamada de praça dos Bambus no início do século XX). De 1938 a 1962 - Segundo projeto para a praça. A partir de 1962, iá denominada praça Tubal Vilela, projeto elaborado pelo engenheiro arquiteto João Jorge Coury. Fonte: Elaboração dos autores a partir das plantas dos projetos em Guerra (1998, p. 66, 70, 137). Fotos da praça da República: Centro de Documentação e Pesquisa em História da Universidade Federal de Uberlândia (CDHIS-UFU).

Foto da praça Tubal Vilela atual: Autores.

Os projetos do engenheiro arquiteto para as praças foram estudados na dissertação de mestrado de Maria Eliza Alves Guerra (1998). 


\subsection{A 1950: O AUGE DA FERROVIA}

Em meados de 1940, a cidade se expande impulsionada pela ferrovia e pelo crescimento econômico da região. Neste momento, já conta com 40 mil habitantes e novos bairros são implantados para abrigar parte desta nova população. Apesar da proximidade do centro, estes bairros são marcados por características sociais distintas.

A cidade amplia os seus limites e surgem as primeiras ocupações periféricas desconectadas do traçado ortogonal. Pode-se caracterizar a cidade, nesta época, com duas zonas distintas: centro e periferia (atual pericentral). Neste período, ocorrem superações dos primeiros obstáculos físicos para dar continuidade à expansão da malha urbana: os córregos Cajubá e São Pedro (ambos ainda sem canalização) e a linha férrea. Os novos bairros cresceram junto aos principais eixos de transporte da cidade: o eixo ferroviário sentido São Paulo e Goiás; o eixo viário sentido Goiás e Prata; o aeroporto (figura 5).

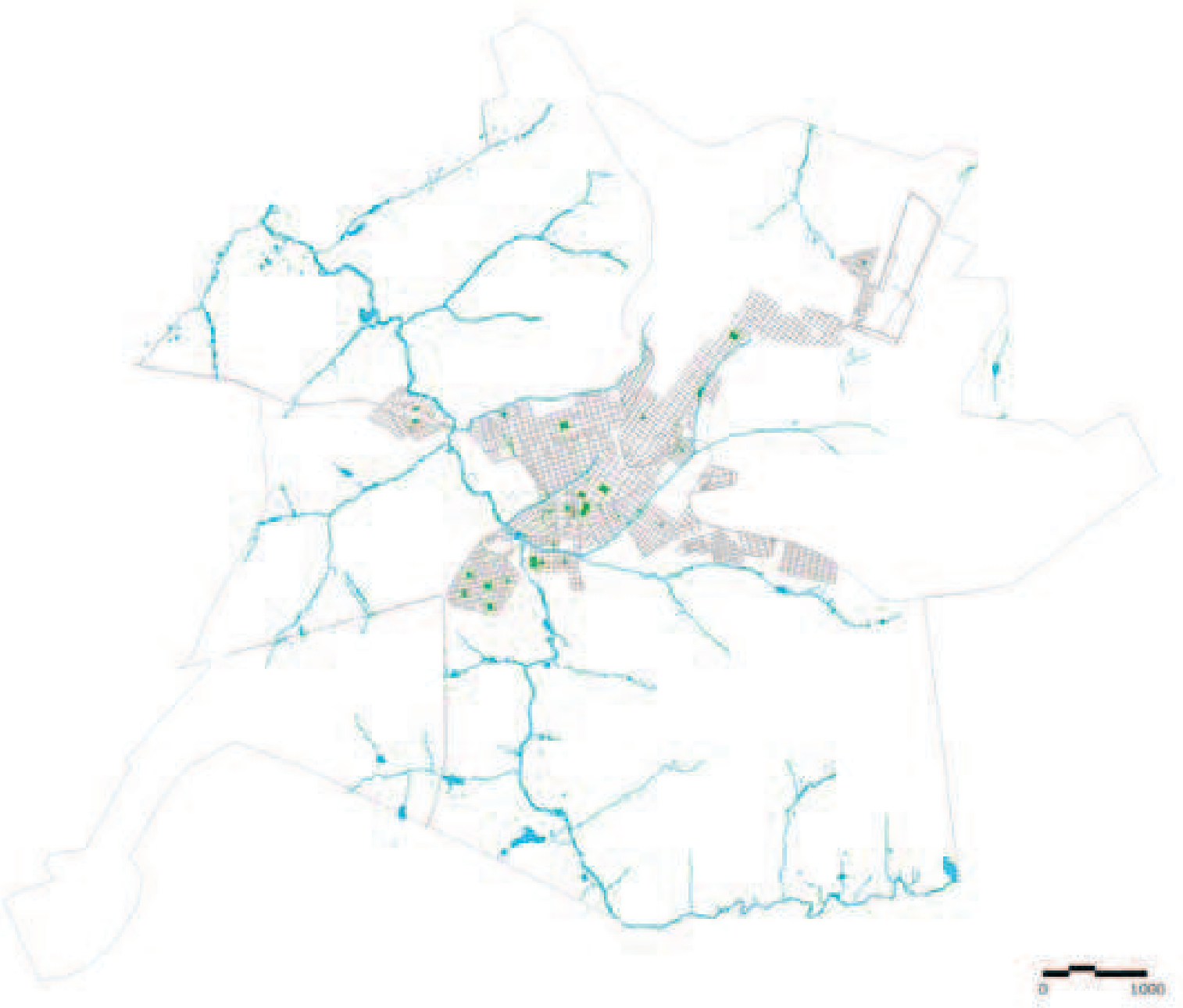

Figura 5 Forma urbana de Uberlândia em 1950.

Adaptação e elaboração: Glauco de Paula Cocozza e Lucas Martins de Oliveira.

Fonte do mapa base: Prefeitura Municipal de Uberlândia.

Embora alguns novos bairros fossem idealizados seguindo alguns conceitos de cidade jardim - com rotatórias e canteiros ajardinados - o padrão da malha ortogonal 
xadrez regeu a maioria dos novos parcelamentos, em uma tentativa de costura entre os novos loteamentos e o centro da cidade, entretanto implantados com quadras e lotes de menor dimensão. Porém, o que se percebe é que a preocupação com os espaços livres, sejam eles funcionais ou áreas de lazer, diminuiu. Poucas praças foram implantadas, apenas a praça Nossa Senhora Aparecida e a Nicolau Feres. A cidade, com baixa densidade de ocupação e poucos carros, tinha a rua como principal elemento de estruturação da vida cotidiana.

Os bairros, então periféricos, serviam de conexão entre o centro e o entorno rural, sendo o eixo ferroviário um grande articulador do espaço urbano, através dos pátios de manobra, dos galpões de armazenamento e dos comércios, que fizeram emergir uma importante área comercial da cidade na atualidade.

Outra característica da urbanização neste período é a consolidação de bairros que surgiram para alocar a população de baixa renda, locados do outro lado do córrego São Pedro - Patrimônio e Saraiva, que impulsionaram a ocupação para a zona sul da cidade. Este modelo de segregação espacial através do suporte geográfico é comum neste período, visto que os rios ainda eram barreiras a serem transpostas. Na época, foi criada a Comissão de Urbanismo, pela Câmara Municipal, com o fim de avaliar os problemas urbanísticos latentes e as péssimas condições de infraestrutura nos bairros.

A leitura desse documento [Atas da Comissão de Urbanismo], além de nos dar uma ideia das condições gerais da cidade - uma grande diferença do grau de infraestrutura existente no centro e na periferia -, mostra também os problemas que já se apresentavam: a necessidade de adoção de uma política de habitação dirigida aos trabalhadores e de coibir o loteamento de área urbana muito além das necessidades de crescimento da população, a canalização de córregos que limitavam a área central e a falta de legislação de controle do crescimento da cidade. (FONSECA, 2007, p. 105).

Com a implantação dos novos loteamentos, a cidade expande seus limites e começa a compor uma trama mais heterogênea, que até então era formada apenas pelo traçado ortogonal da região central, agregando novas morfologias e categorias de espaços livres, principalmente a viária.

\subsection{A 1970: MODERNIZAÇÃO AGRÍCOLA E TRANSPOSIÇÃO DA FERROVIA}

A canalização do córrego Cajubá marca o início da transformação dos cursos d'água em infraestrutura viária em Uberlândia. $\bigcirc$ córrego dá lugar à avenida Rio de Janeiro (atual Getúlio Vargas), e, assim, os fundos de vale deixam de ser barreiras e começam a ser incorporados ao tecido urbano - de forma equivocada, mas transformando definitivamente a paisagem da atual região central (figura 6).

Soma-se a este pensamento o modelo de parcelamento, definido por novas estruturas de espaços livres, largas avenidas arborizadas e praças originadas pelo traçado viário 
radial, formando rotatórias e espaços livres nos cantos das quadras. Outro ponto de transformação é a construção dos primeiros edifícios verticais - notadamente voltados à população de alta renda -, o que marca o início do processo de adensamento da região central, alterando o seu padrão morfológico. Edifícios modernos são construídos, substituindo muitas das antigas construções dos dois períodos anteriores, dando uma nova conotação à paisagem urbana.

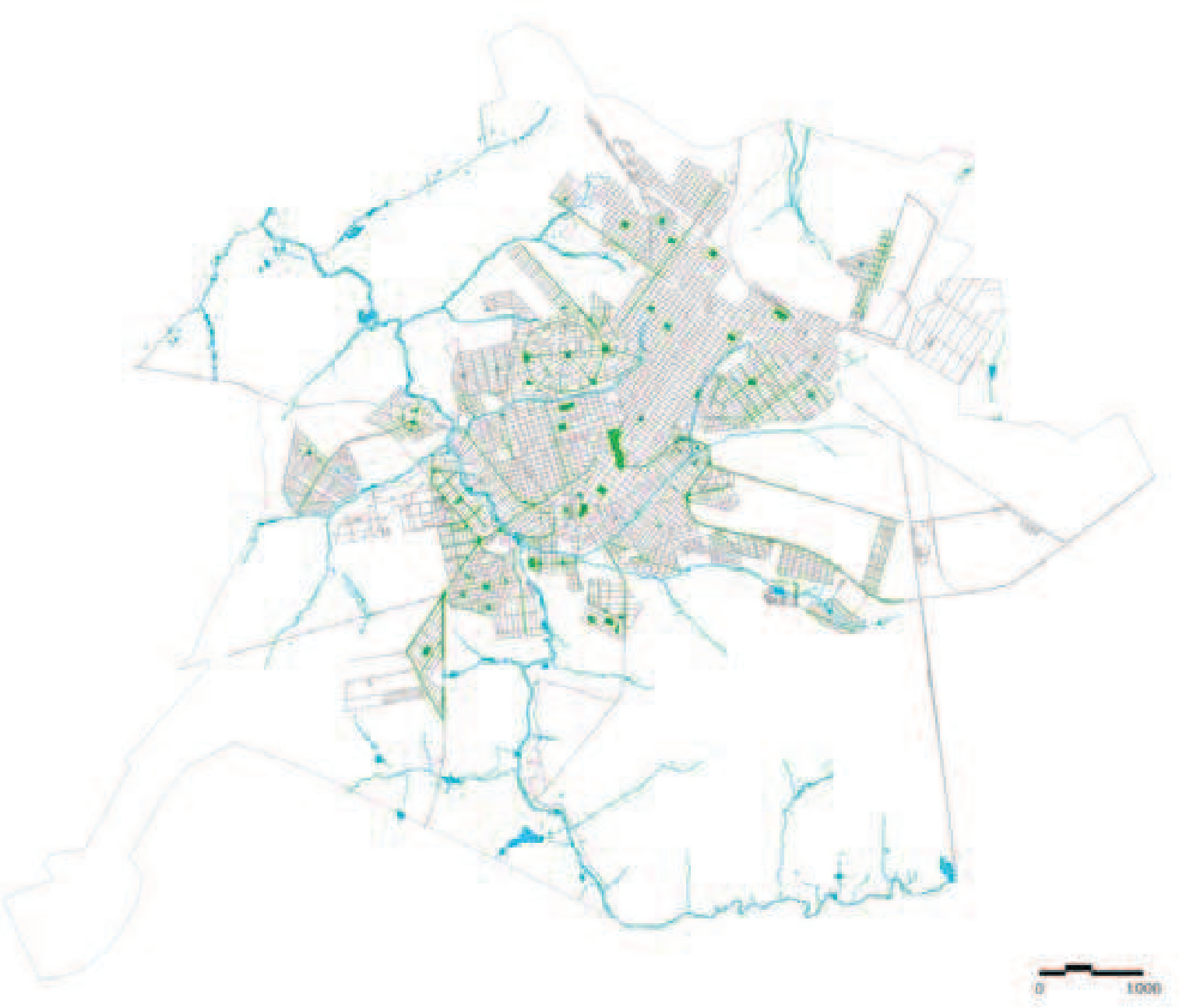

Figura 6 Forma urbana de Uberlândia em 1970.

Adaptação e elaboração: Glauco de Paula Cocozza e Lucas Martins de Oliveira.

Fonte do mapa base: Prefeitura Municipal de Uberlândia.

Assim como no período anterior, experimentações de traçados urbanos são executadas em novos bairros, sendo o Roosevelt o mais significativo em termos morfológicos, com traçado irregular e sistema viário circular, com vias radiais conectadas por praças. Este modelo é marcante no tecido urbano de Uberlândia, e outros parcelamentos são estruturados com este modelo, onde o sistema viário adquire uma importância maior na organização dos espaços livres.

Tal modelo seguia os princípios urbanísticos que se desenvolviam no interior do Brasil, tendo, como principal expoente, Goiânia, cidade planejada com influência da cidade jardim e que despontava como exemplo de qualidade urbana, com o desenho 
se adequando ao suporte físico, com avenidas arborizadas, ruas sinuosas e praças que complementavam o sistema viário, locadas em áreas estratégicas dentro do tecido urbano.

Estes bairros, então periféricos, são marcados na atualidade pela falta de manutenção dos espaços livres, visto que o seu acréscimo foi grande, prejudicando a sua condição no sistema que continuava a se moldar. Neste período, a cidade atingiu uma população de 95 mil habitantes, impulsionada pelo desenvolvimento da região Centro- Oeste do Brasil, principalmente com a construção de Brasília, que consolidaria o eixo de crescimento para o interior do país.

Com o rápido crescimento, houve a necessidade de que novos bairros fossem abertos, aumentando a oferta de lotes, o que ocorreu sem nenhum planejamento prévio, muitas vezes favorecendo apenas o dono da terra em detrimento da qualidade urbana:

A ausência de planos urbanísticos ou normativas que norteassem o crescimento físico da cidade fazia com que projetos de novos loteamentos fossem aprovados sem muito critério técnico ou exigências, o que resultava num tecido urbano descontínuo e na criação de novos bairros totalmente sem infraestrutura. Era frequente a desapropriação de terrenos para a abertura, continuidade, alargamento ou retificação de ruas ao redor do Centro ou dos bairros mais próximos. A falta de terrenos para a implantação de praças, escolas e hospitais era habitual e levava, com frequência, o município a desapropriar áreas ou negociar, diretamente com os loteadores, a doação de áreas para tais fins. Os projetos de novos loteamentos eram aprovados pela própria Câmara Municipal e, visto que muitos loteadores eram os próprios prefeitos ou pessoas diretamente ligadas a eles, poucas exigências eram feitas ou até mesmo se permitia a aprovação de loteamentos fora do perímetro urbano. [...] $\mathrm{Na}$ verdade, a cidade sofria as consequências da falta de uma legislação urbanística que impedia o crescimento excessivo do tecido urbano. Uberlândia, nessa época, apresentava uma rede urbana extensa, com baixa densidade de ocupação entrecortada por grandes vazios urbanos. (FONSECA, 2007, p. 106).

A descontinuidade do tecido neste período é determinante para a configuração da forma atual de Uberlândia. A implantação dos loteamentos periféricos afastados marca a expansão urbana em direção às regiões oeste e leste, sendo estes os vetores de crescimento urbano a serem explorados, na época, pelas empresas imobiliárias.

Com a implantação dos loteamentos Altamira e Cidade Jardim, na região sul, inicia-se o processo de saída das classes média e alta da região central da cidade, que optam por bairros mais afastados e com outro contexto urbano. Estes bairros caracterizam-se pela boa condição de espaços livres privados, em função do tamanho dos lotes, em média com $1.000 \mathrm{~m}^{2}$.

Uma grande intervenção urbana marca a transição do fim deste período: a mudança dos trilhos para o norte da cidade. A barreira física causada pela presença dos trilhos e da estação ferroviária, na região central, motiva a construção de uma nova linha férrea e de uma nova estação na periferia da cidade. $\bigcirc$ antigo pátio ferroviário, 
motivo de grandes discussões, dá lugar à atual praça Sérgio Pacheco, e um novo sistema viário é construído na antiga linha férrea, atual avenida João Naves de Ávila, hoje eixo estruturador da cidade (figuras 7, 8 e 9).

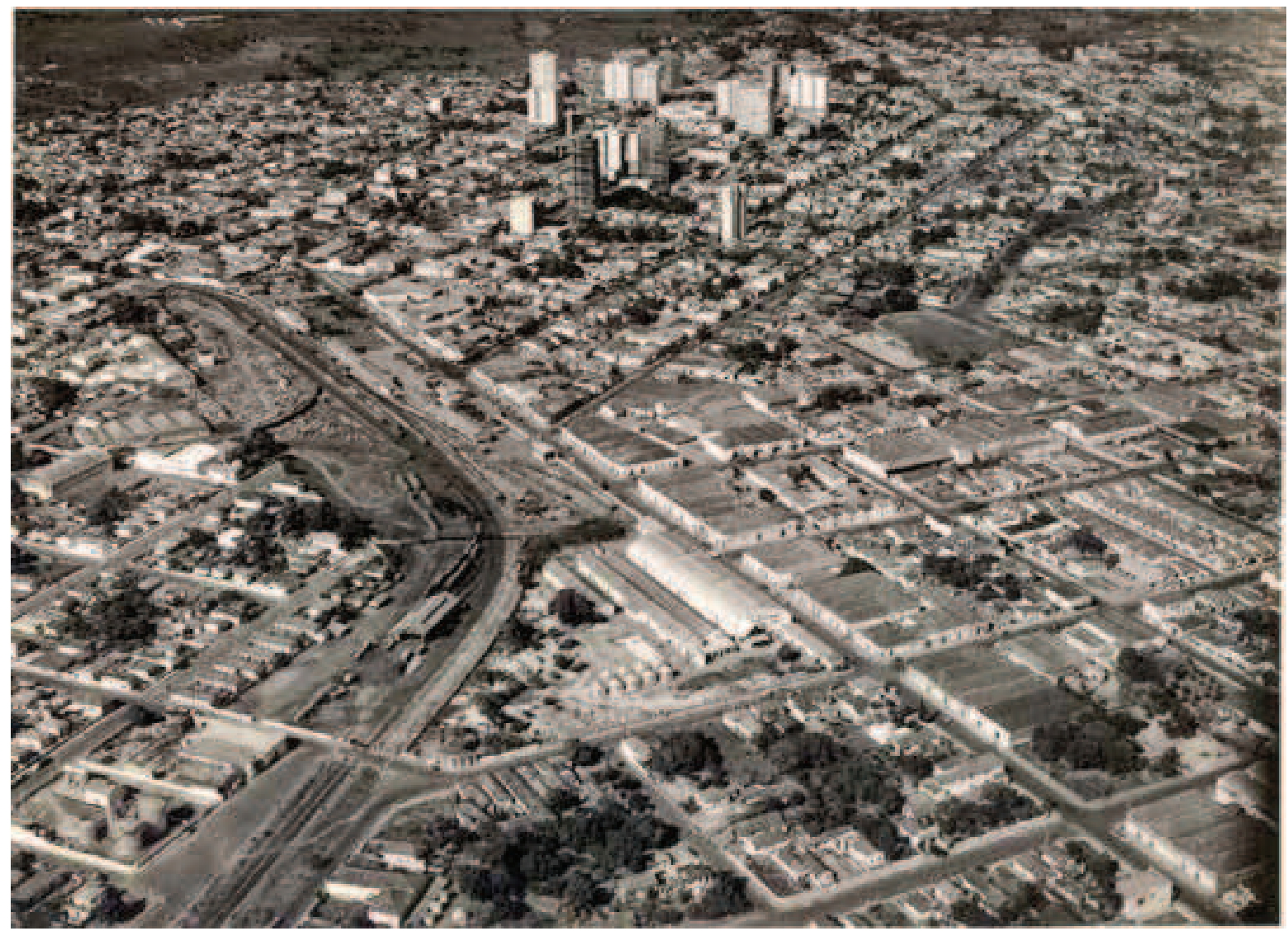

Figura 7 Pátio da ferrovia Mogiana, ainda em uso, em 1970.

Fonte: Acervo Arquivo Público de Uberlândia - 2012.

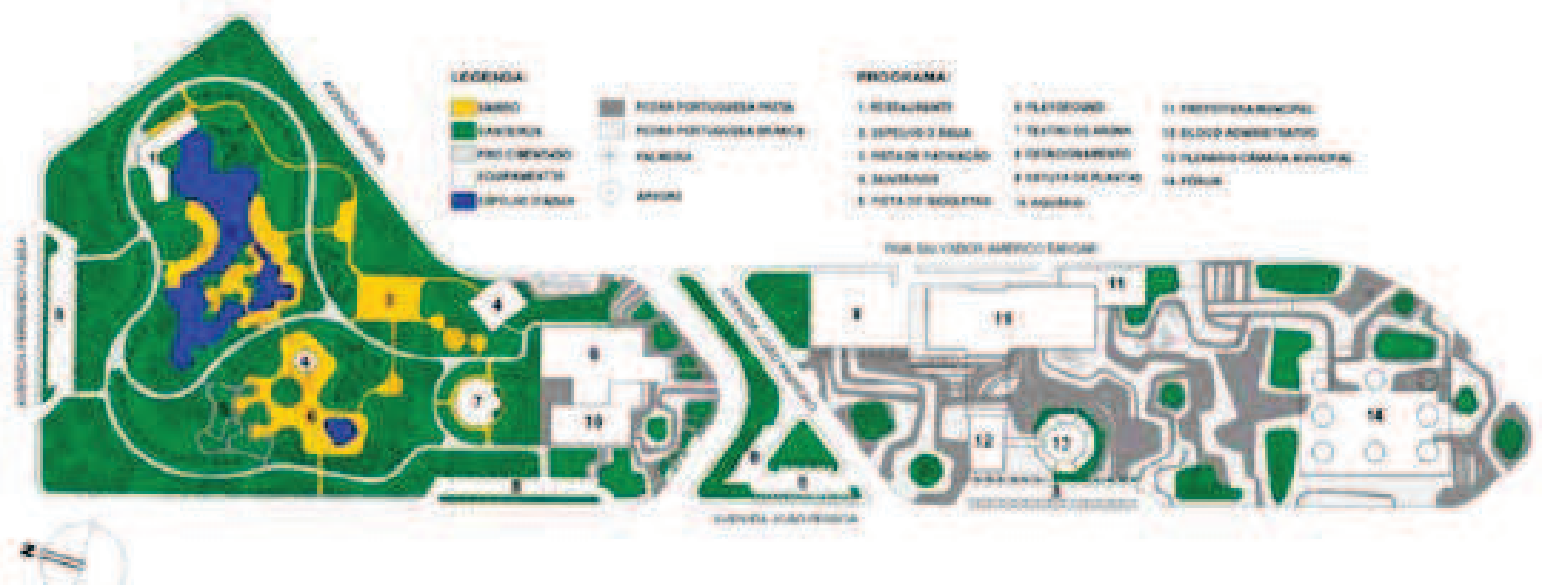

Figura 8 Planta do projeto de Ary Garcia Roza e Roberto Burle Marx, gerada a partir das fotos da planta do projeto original, para a praça Sérgio Pacheco.

Desenho elaborado por Kavê Felipe Paiva para o projeto de pesquisa Documentação da Arquitetura Moderna no Triângulo Mineiro e Alto Paranaíba: História e Preservação. Acervo do arquivo do Núcleo de Teoria e História da Arquitetura e Urbanismo - FAUeD/UFU. Fonte: Paiva e Cappello (2011, p. 21). 


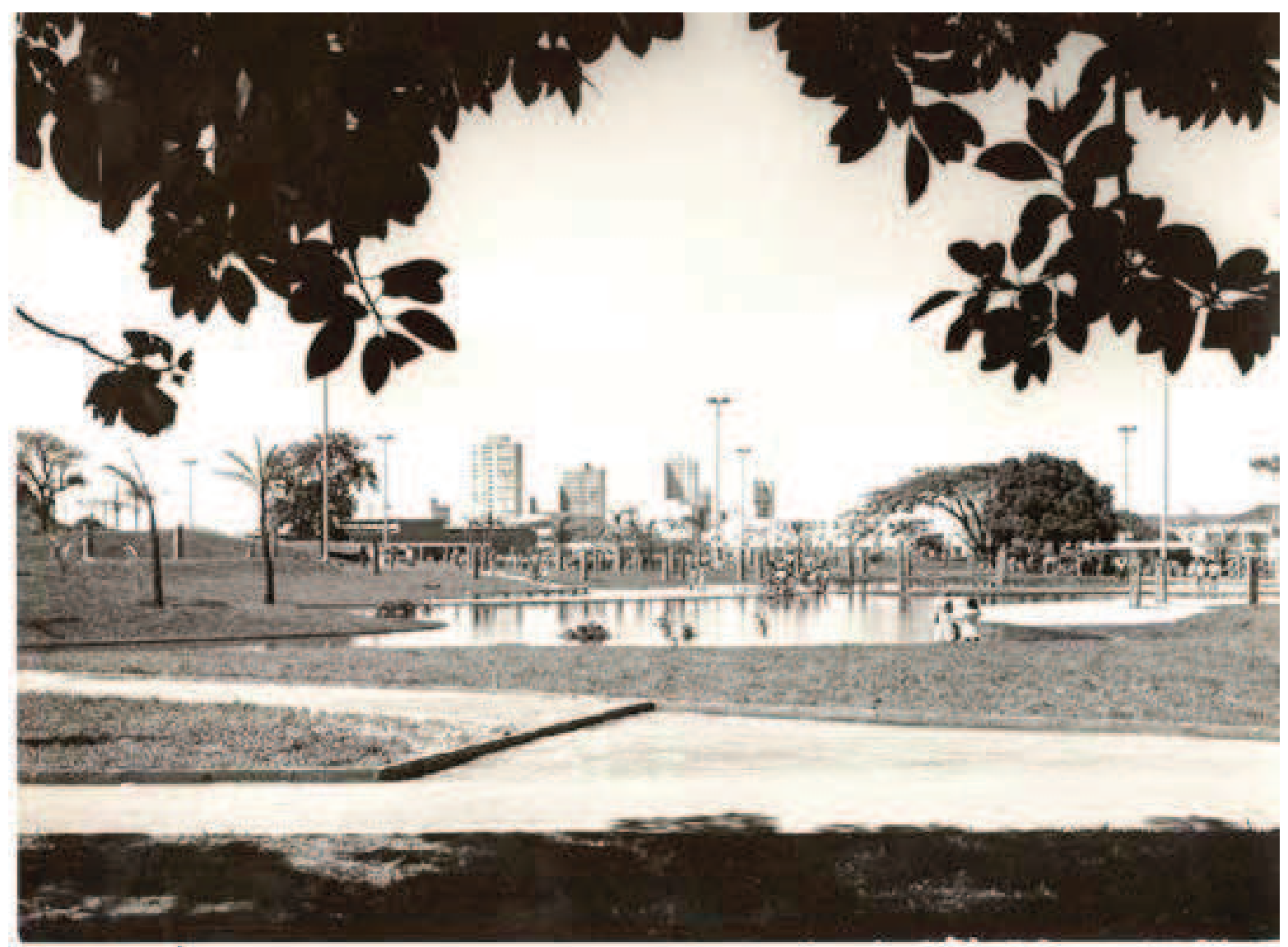

Figura 9 Inauguração da praça Sérgio Pacheco na década de 1970. Fonte: Acervo Arquivo Público de Uberlândia - 2012.

\subsection{A 1980: DESENVOLVIMENTO LOGÍSTICO DA REGIÃO}

Com o crescimento econômico do interior do Brasil e uma política governamental de incentivo às cidades médias, Uberlândia cresce em importância e torna-se um ponto nodal de ligação entre o Sul e o Norte do Brasil. O intenso movimento de carga nas vias urbanas fez com que se tornasse necessária a construção de vias de escoamento, efetivando política rodoviarista. As estradas fragmentaram parte do tecido urbano e redesenharam o seu crescimento, transferido para a qualificação de outro setor da cidade, a zona sul.

O consequente crescimento populacional fez surgir novos loteamentos, construídos nas regiões periféricas da cidade, junto aos novos polos de distribuição, efetivando-se, assim, a ocupação destas áreas pela população de baixa renda (figura 10). Como em muitas cidades brasileiras, tais localidades sofrem com o descaso dos gestores, com a falta de infraestrutura básica e com a falta de espaços livres. Estes, que anteriormente se distribuíam de modo mais equilibrado, agora são negligenciados por parcelamentos precários e de pouca qualidade espacial.

Como reflexo destes acontecimentos, a prefeitura iniciou um conjunto de obras de qualificação do sistema viário para o escoamento de mercadorias e da população, sendo o mais marcante a implantação da avenida Rondon Pacheco, marco da trans- 
formação da paisagem na cidade, e a avenida Anselmo Alves dos Santos - ambas com canalizações de córregos -, que conecta o centro ao parque do Sabiá, maior e mais importante área verde de Uberlândia.

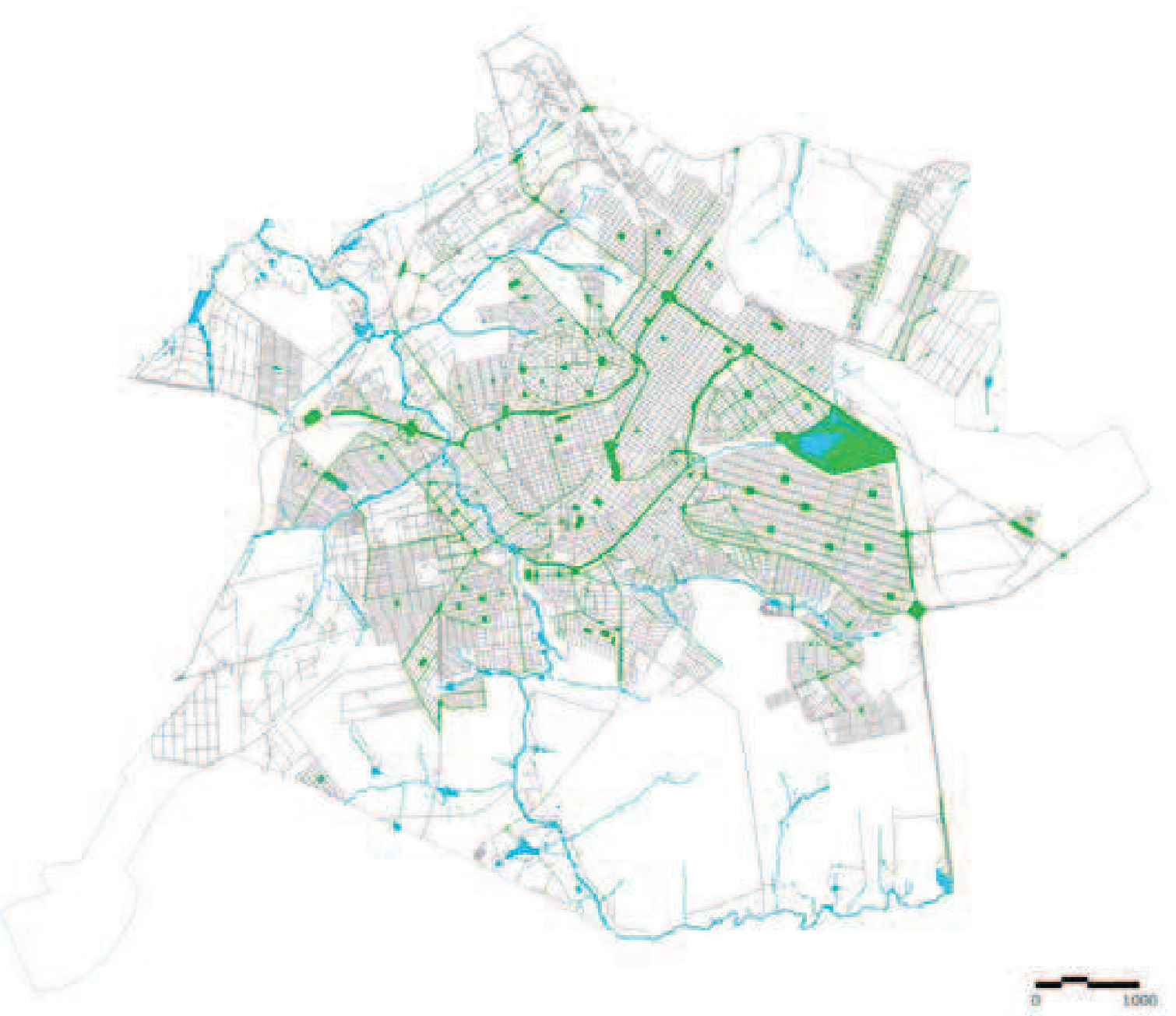

Figura 10 Forma urbana de Uberlândia em 1980.

Adaptação e elaboração: Glauco de Paula Cocozza e Lucas Martins de Oliveira.

Fonte do mapa base: Prefeitura Municipal de Uberlândia.

Ao mesmo tempo, o bairro Santa Mônica é implantado na colina entre a antiga linha do trem e o parque do Sabiá, tendo como base do seu desenho ruas e avenidas largas e extensas áreas de praças em meio ao parcelamento ortogonal - porém não mais com quadras de 100x100, mas retangulares, de 70x180, padrão nos novos loteamentos urbanos. As praças desenhadas neste período ainda estão para ser implantadas, o que mostra o descaso dos gestores com essa categoria de espaço.

No ano de 1979, é aprovada a Lei Federal n ${ }^{\circ}$ 6766, que regulamenta o parcelamento do solo urbano nas cidades. Entre outros aspectos abordados pela mesma, ela define o papel do espaço livre público nos novos loteamentos. Embora a obrigatoriedade deste tipo de espaço pudesse projetar espaços mais qualitativos, o mesmo começa a ser utilizado apenas como elemento para a aprovação da gleba perante órgãos municipais, perdendo a sua essência como forte estruturador do desenho. 


\subsection{A 2000: INDUSTRIALIZAÇÃO E CONSOLIDAÇÃO COMO POLO REGIONAL}

Com as facilidades de escoamento de mercadorias, a existência de infraestrutura e boa qualidade de vida, diversas indústrias começam a instalar-se na cidade, consolidando o atual Distrito Industrial, na região norte, e, consequentemente, o aumento da demanda por habitação em seu entorno. $O$ crescimento econômico, impulsionado também pela modernização do setor agrícola, promove nova transformação do tecido urbano de Uberlândia, tornando-o mais complexo, problemático, carente de novas normativas e planejamento. A cidade precisa de novos bairros, e, novamente, a baixa qualidade espacial marca os novos loteamentos. Os espaços livres, como praças e parques, embora apareçam nos projetos, não são implantados e muitas vezes são ocupados para outro fim.

Em 1980 a população da cidade atinge 230 mil habitantes, e cada vez mais a fragmentação do tecido urbano promove a segregação espacial de suas regiões. Como consequência do rápido crescimento, graves problemas relativos à forma de ocupação do sítio começam a ocorrer: enchentes, polvição dos rios e córregos, desmatamento de matas ciliares e remanescentes de cerrado, congestionamentos nas áreas centrais (figura 11).

Neste cenário, a população de alta renda busca novas possibilidades de moradia, sendo que a mudança é facilitada com a implantação de novos bairros na região sul. Surge assim o loteamento Jardim Karaíba, que transformaria a paisagem da cidade (figura 12). O bairro torna-se o principal ponto de atração e seu parcelamento configura-se em extensos jardins frontais nas casas, que não poderiam ter muros, o que logo se torna a imagem da qualidade urbana que Uberlândia almejava e que se perdera com a construção de bairros populares na região periférica. Os novos empreendimentos precisavam resgatar o papel do espaço livre como elemento de qualidade espacial. Era a Uberlândia ajardinada, moderna e próspera.

$\mathrm{Na}$ época, junto a este loteamento, tentou-se construir o primeiro shopping da cidade, porém, por questões de acessibilidade, não vingou. $O$ shopping que iria transformar o contexto urbano foi inaugurado no começo da década de 1990, no cruzamento das duas principais avenidas da cidade, tornando-se marco na paisagem e no contexto urbano local.

\subsection{ATÉ OS DIAS ATUAIS: DESENVOLVIMENTO DO SETOR DE SERVIÇOS}

Com a chegada do século XXI, a zona sul firma-se como local de moradia e desejo das classes média e alta, emergentes do crescimento econômico da cidade. Próximos ao Jardim Karaíba surgem os primeiros loteamentos fechados, influenciados pelo padrão espacial herdado deste bairro e marcando a transformação do setor imobiliário e produtivo da cidade. Assim como em muitas cidades do interior do Brasil, a construção de condomínios fechados, em áreas estratégicas - no caso, a zona sul -, marca 


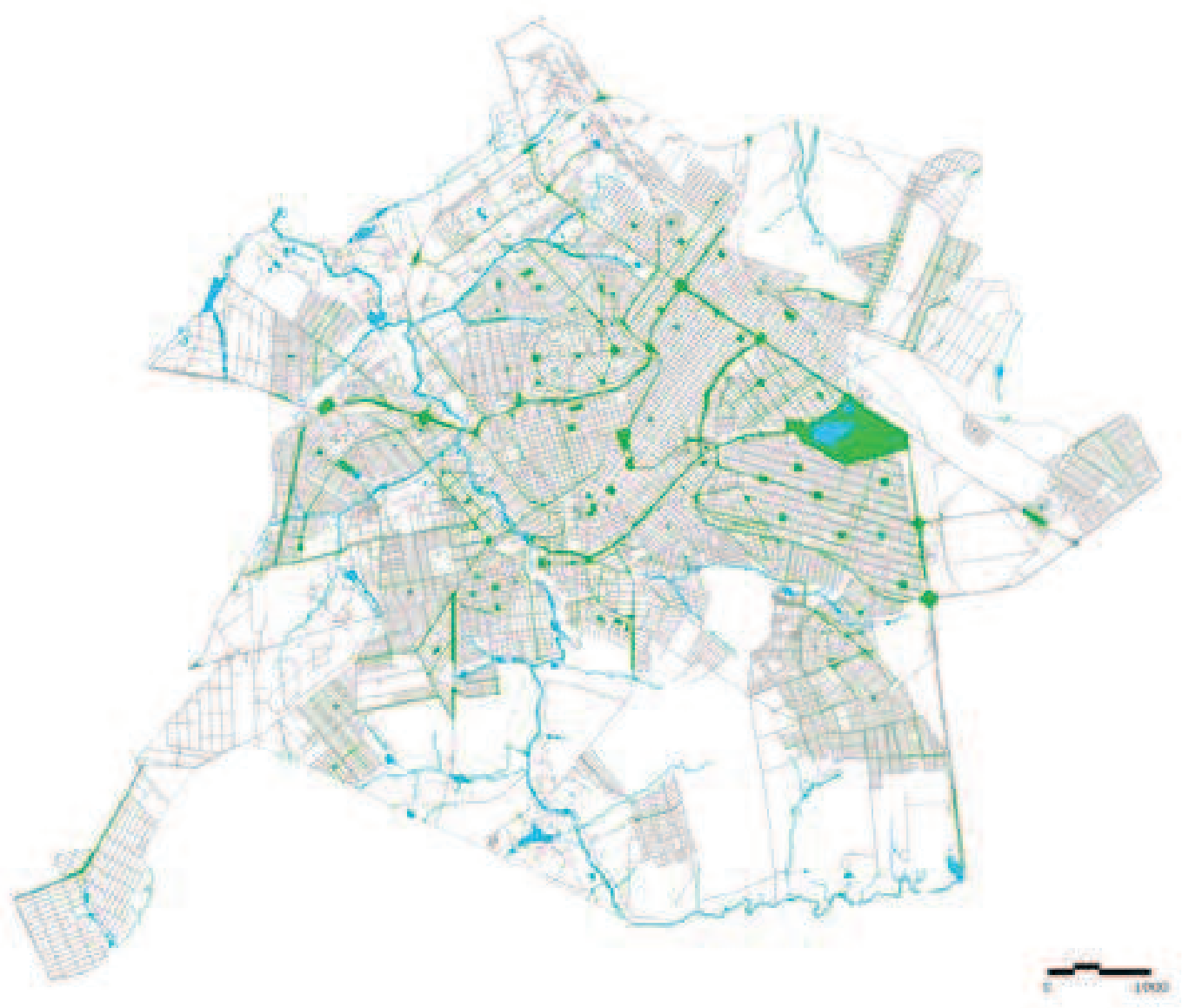

Figura 11 Forma urbana de Uberlândia em 1990.

Adaptação e elaboração: Glauco de Paula Cocozza e Lucas Martins de Oliveira, 2011. Fonte do mapa base: Prefeitura Municipal de Uberlândia.

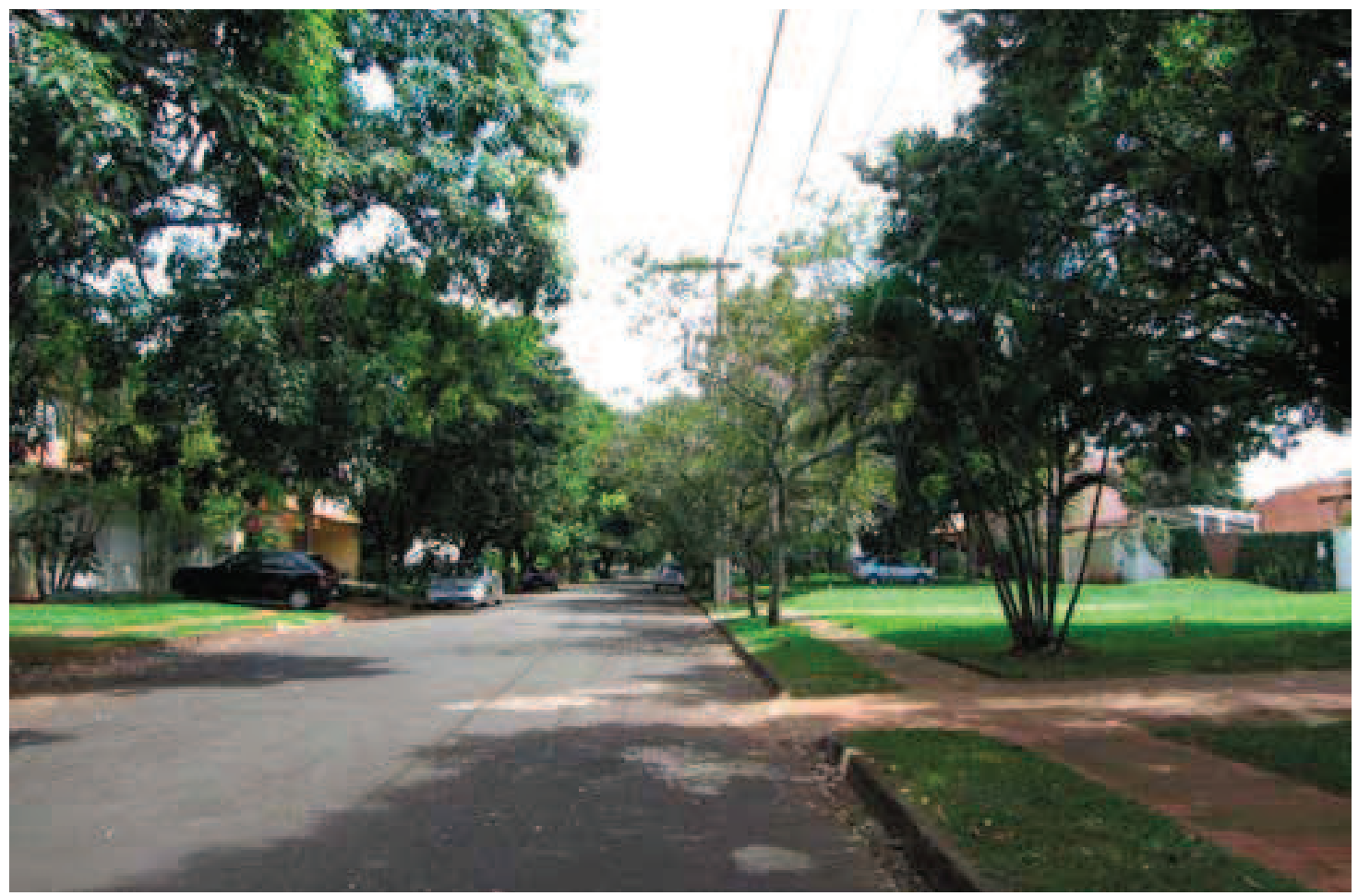

Figura 12 Bairro Jardim Karaíba.

Fonte: Acervo do Núcleo de Estudos Urbanos e Regionais da Universidade Federal de Uberlândia (NEUrb-UFU) - 2012. 
a segregação espacial, que ganha força na última década. A elite, que anteriormente vivia no centro, e que passou, depois, por bairros residenciais, instala-se nos diversos loteamentos fechados criados na área de expansão. Isto fez surgir uma nova centralidade, com universidades, shopping e áreas de lazer destinadas a esta população (figura 13).

Se por um lado a região sul cresce como local das classes mais abastadas, nas suas franjas novos bairros populares são implantados. Novamente, são loteamentos urbanos onde o espaço livre é apenas uma taxa, locados no projeto para aprovação, porém, não implantados. Um fator importante que marca a paisagem urbana das novas regiões periféricas é a explosão de novas construções para a população de baixa renda, com subsídio do governo federal, favorecida pelo programa Minha Casa, Minha Vida (figura 14).

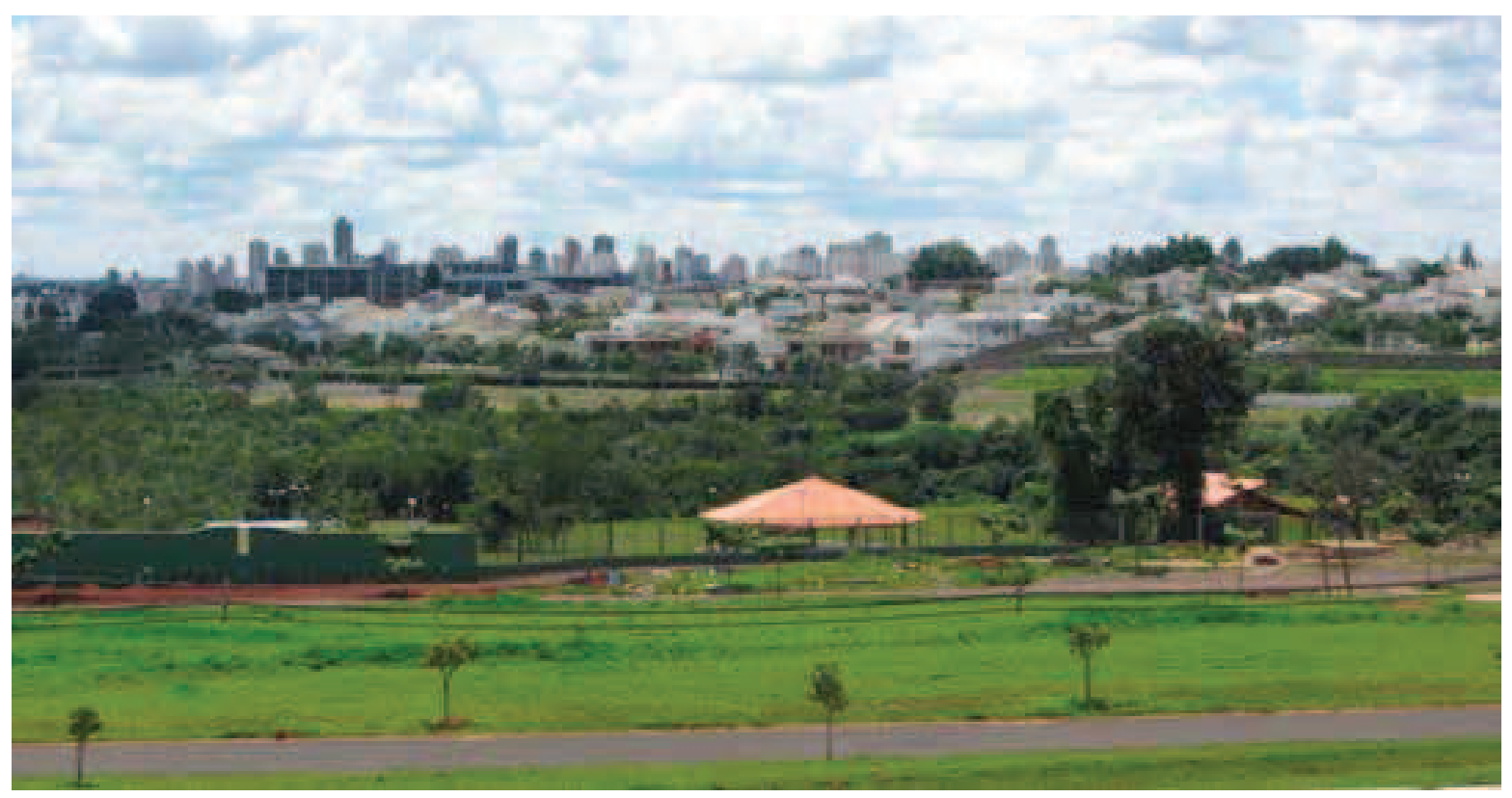

Figura 13 Condomínios voltados para Área de Preservação Permanente (APP) - Região central ao fundo. Fonte: Acervo do Núcleo de Estudos Urbanos e Regionais da Universidade Federal de Uberlândia (NEUrb-UFU) 2012.

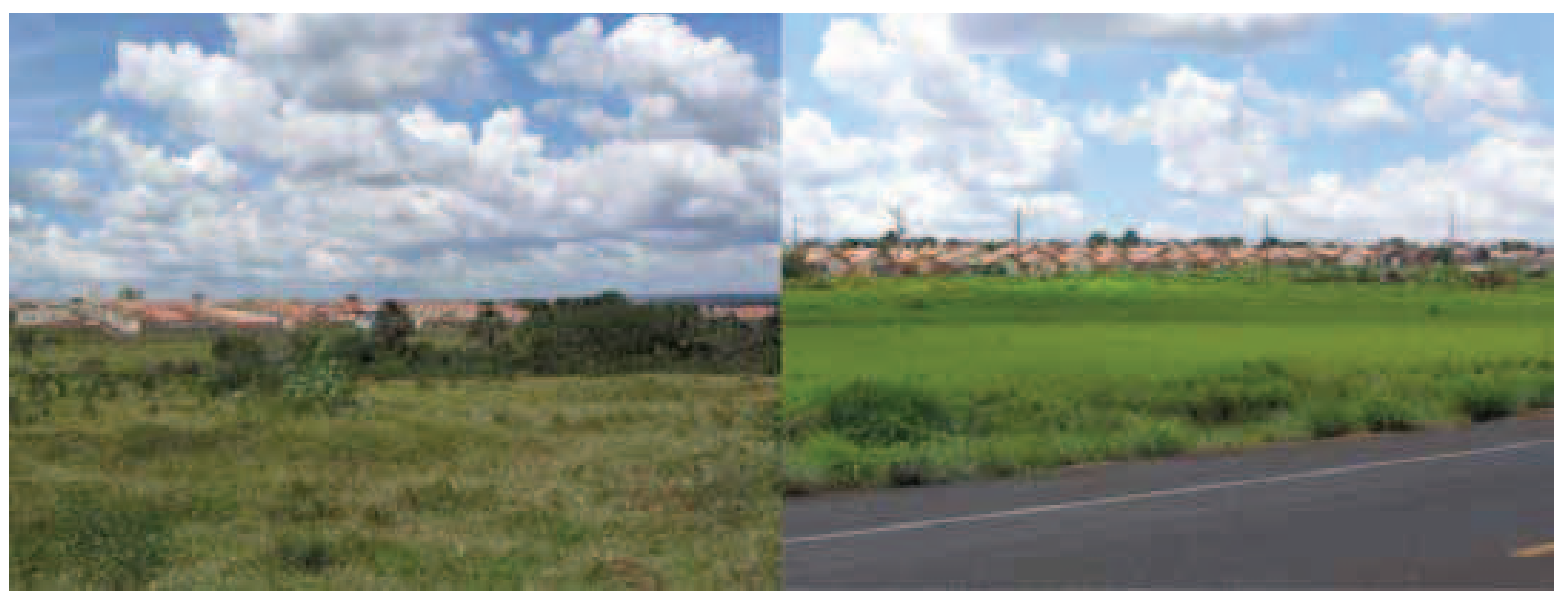

Figura 14 Loteamentos implantados nas franjas da zona sul.

Fonte: Acervo do Núcleo de Estudos Urbanos e Regionais da Universidade Federal de Uberlândia (NEUrb-UFU) 2012. 
Este modelo de loteamento, que definia a paisagem de outras áreas, agora forma um anel que define o limite entre a área urbana e a periurbana. Muitos fundos de vale são incorporados ao tecido urbano, porém sem ocupação e intervenção do Estado. Tal potencial da cidade descreve uma característica destacada na atualidade, a do grande potencial ambiental sistêmico proporcionado pelos fundos de vale (figura 15).

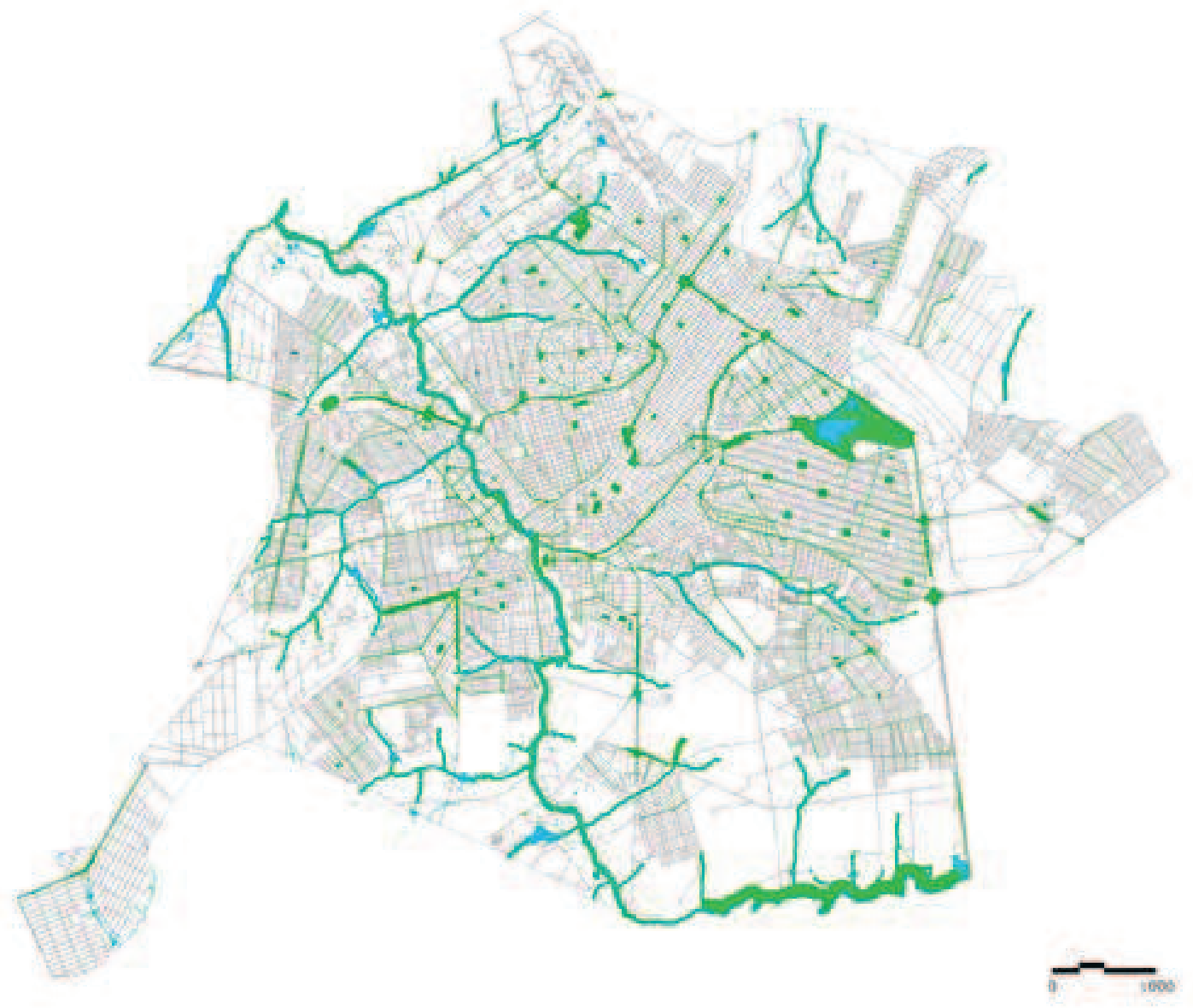

Figura 15 Forma urbana de Uberlândia em 2000.

Adaptação e elaboração: Glauco de Paula Cocozza e Lucas Martins de Oliveira.

Fonte do mapa base: Prefeitura Municipal de Uberlândia.

Assim como ocorreu em outras cidades no Brasil e no mundo, a questão ambiental emergiu como uma das principais bandeiras de políticos e entidades de classes e civis na busca de uma cidade mais sustentável. Como política do meio ambiente local, novos parques urbanos municipais são criados em áreas de proteção ambiental, com destaque para o Parque Linear do rio Uberabinha², que tem como principal objetivo criar um eixo de lazer, cultura e educação ambiental ao longo do trecho mais urbanizado do rio, costurando a área central com os bairros antes segregados (figura 16). Esta tentativa de reencontro com a natureza transformou a paisagem do entorno, porém, o mesmo tratamento dado ao principal curso d'água não é visto em outros córregos da bacia 
do rio Uberabinha, mantendo o grande potencial ambiental para intervenções futuras, que transformarão ainda mais a forma urbana de Uberlândia. A paisagem das bordas forma um conjunto de áreas que potencializam a criação de um sistema, conectando diferentes áreas do tecido, tanto na área central como nas regiões periféricas.

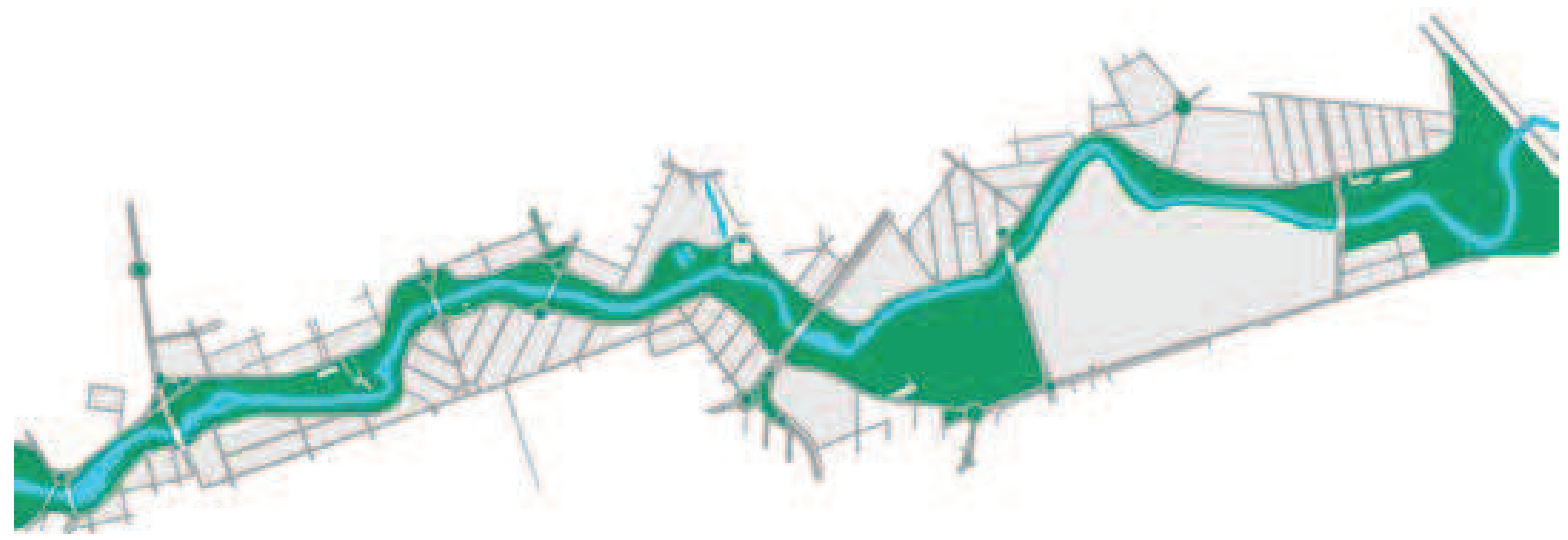

Figura 16 Implantação geral do projeto Parque Linear Uberabinha.

Fonte: Núcleo de Memórias e Referências - Faculdade de Arquitetura e Urbanismo e Design da Universidade Federal de Uberlândia (FAUeD/UFB).

\section{CONSIDERAÇÕES FINAIS}

Resgatar as transformações do tecido urbano das cidades significa identificar o processo de produção do seu espaço. Este estudo permitiu compreender a configuração dos espaços livres ao longo do tempo e visualizar com quais decisões e em que contextos o atual sistema se configurou. A análise desta organização não deve ser somente espacial, mas econômica, política e social, indicando as possíveis variáveis que definem o Sistema de Espaços Livres (SELs) pelas cidades brasileiras.

Dois aspectos podem ser apontados quando se abordam os espaços livres urbanos na cidade de Uberlândia. O primeiro refere-se à perda da sua condição qualitativa, seja pela esfera pública e pelo lócus identitário da vida cotidiana, assim como a do seu papel na organização do tecido urbano. Muitas praças só existem no papel e são desenhadas apenas para compor porcentagens, ao invés de servirem a um pensamento urbanístico que as valorize, fato este que ocorre principalmente nas regiões periféricas. Porém, são nestas regiões que a rua se mantém como principal espaço público e de lazer da população.

Um fato que vale ressaltar é a tentativa de aproximar as áreas de fundos de vale com a trama da cidade. Embora sejam áreas destinadas à preservação, protegidas pela legislação federal, contradições ainda permeiam sua gestão municipal: são espaços de conflitos ambientais e territoriais, palcos de tensões urbanas. Muitas são parques somente no papel; outras são usadas para infraestrutura da paisagem, como corredores ecológicos; outras destinadas à implantação de equipamentos sociais. De fato, são espaços que deveriam e poderiam se caracterizar por uma efetiva ação municipal, que garantisse sua territorialidade pública e de usufruto coletivo. 
O segundo aspecto é a gestão deste sistema na cidade. $O$ crescimento econômico e populacional faz com que a cidade priorize intervenções no sistema viário para o transporte individual, no sistema de abastecimento de água e energia, porém pouco se faz para o sistema de espaços livres urbanos. Nada diferente de outras cidades, porém percebe-se que o espaço livre público perde seu valor e seu significado - e outros espaços, como clubes e condomínios prevalecem como espaços de lazer e integração, principalmente pela falta de manutenção dos espaços públicos, prejudicando cada vez mais uma efetiva apropriação da população.

Mesmo assim, ainda temos um sistema que se estrutura e se potencializa com o entendimento do papel da natureza na cidade. $\bigcirc$ quadro abaixo sintetiza os resultados desta pesquisa, comparando os principais aspectos abordados nos levantamentos, caracterizando os períodos e os principais componentes da transformação do espaço livre na forma urbana.

\section{QUADRO COMPARATIVO DOS ESPAÇOS LIVRES EM CADA PERÍODO}

\begin{tabular}{|c|c|c|c|c|}
\hline $\begin{array}{l}\text { Aspectos } \\
\text { Período }\end{array}$ & $\begin{array}{c}\text { CONTEXTO } \\
\text { POLÍTICO E } \\
\text { SOCIOECONÔMICO }\end{array}$ & $\begin{array}{c}\text { LEGISLAÇÃO } \\
\text { AMBIENTAL E } \\
\text { URBANA }\end{array}$ & $\begin{array}{c}\text { PADRÕES } \\
\text { URBANÍSTICOS }\end{array}$ & ESPAÇOS LIVRES \\
\hline $\begin{array}{l}\text { Fundação } \\
\text { a } 1920\end{array}$ & $\begin{array}{l}\text { Sociedade rural. } \\
\text { Economia rural e } \\
\text { extensiva. }\end{array}$ & $\begin{array}{l}\text { Códigos } \\
\text { de Posturas } \\
\text { Coloniais. } \\
\text { Sem legislação } \\
\text { municipal bem } \\
\text { definida. }\end{array}$ & $\begin{array}{l}\text { Início sem } \\
\text { planificação rígida; } \\
\text { aglomerado no } \\
\text { entorno na lgreja } \\
\text { Católica. } \\
\text { Primeiro } \\
\text { ordenamento } \\
\text { territorial } \\
\text { promovido pela } \\
\text { ferrovia Mogiana } \\
\text { em malha } \\
\text { ortogonal. } \\
\text { O padrão } \\
\text { de quadra } \\
\text { ortogonal rege os } \\
\text { parcelamentos. }\end{array}$ & $\begin{array}{l}\text { Núcleo inicial: espaço } \\
\text { livre estruturador da forma } \\
\text { urbana. Adro religioso, } \\
\text { largo do comércio, parada } \\
\text { de tropas, cemitério. } \\
\text { Expansão projetada: } \\
\text { primeiro espaço livre } \\
\text { pensado para fins } \\
\text { específicos: praça dos } \\
\text { bambus, atual Tubal Vilela } \\
\text { (racionalismo). A ausência } \\
\text { de legislação específica } \\
\text { prejudica a implantação } \\
\text { e distribuição de espaços } \\
\text { livres. }\end{array}$ \\
\hline $\begin{array}{l}1920 a \\
1950\end{array}$ & $\begin{array}{l}\text { Prolongamento da } \\
\text { Ferrovia Mogiana } \\
\text { e crescimento } \\
\text { para o interior } \\
\text { impulsionam a } \\
\text { economia. }\end{array}$ & $\begin{array}{l}\text { Criação da } \\
\text { Comissão de } \\
\text { Urbanismo } \\
\text { pela Câmara } \\
\text { Municipal. }\end{array}$ & $\begin{array}{l}\text { Novos } \\
\text { parcelamentos } \\
\text { junto ao centro, } \\
\text { com padrão } \\
\text { ortogonal. } \\
\text { A cidade } \\
\text { ultrapassa o } \\
\text { limite físico do rio } \\
\text { Uberabinha. }\end{array}$ & $\begin{array}{l}\text { Poucas praças projetadas. } \\
\text { Prioridade para ruas e } \\
\text { calçadas. } \\
\text { Papel higienista dos } \\
\text { espaços livres. } \\
\text { Arborização urbana. }\end{array}$ \\
\hline
\end{tabular}




\begin{tabular}{|c|c|c|c|c|}
\hline $\begin{array}{l}1950 a \\
1970\end{array}$ & $\begin{array}{l}\text { Construção de } \\
\text { Brasília. } \\
\text { Plano de metas } \\
\text { JK: Uberlândia se } \\
\text { favorece com a } \\
\text { rodoviarização. } \\
\text { Modernização } \\
\text { agrícola. Início } \\
\text { da verticalização } \\
\text { da região central. } \\
\text { Problemas crônicos } \\
\text { de infraestrutura } \\
\text { urbana. }\end{array}$ & & $\begin{array}{l}\text { Novas } \\
\text { experimentações } \\
\text { urbanísticas } \\
\text { - Jaraguá e } \\
\text { Roosevelt. } \\
\text { Primeiros } \\
\text { loteamentos } \\
\text { voltados à } \\
\text { população de } \\
\text { alta renda. Clara } \\
\text { influência dos } \\
\text { projetos urbanos } \\
\text { de Belo Horizonte } \\
\text { e Goiânia. }\end{array}$ & $\begin{array}{l}\text { Transposição da ferrovia } \\
\text { dando lugar a um novo } \\
\text { eixo estrutural. } \\
\text { Espaços livres vinculados } \\
\text { ao desenho viário. } \\
\text { Grandes avenidas } \\
\text { arborizadas. }\end{array}$ \\
\hline $\begin{array}{l}1970 a \\
1980\end{array}$ & $\begin{array}{l}\text { Desenvolvimento } \\
\text { do comércio } \\
\text { atacadista. } \\
\text { Periferização. }\end{array}$ & $\begin{array}{l}\text { Lei n. }{ }^{\circ} 6766 \\
1979\end{array}$ & $\begin{array}{l}\text { Novos } \\
\text { parcelamentos, } \\
\text { com predomínio de } \\
\text { tecido urbano em } \\
\text { padrão retangular, } \\
\text { propiciando a } \\
\text { maximização } \\
\text { dos lucros em } \\
\text { detrimento das } \\
\text { dimensões dos } \\
\text { lotes. Espaço livre } \\
\text { tratado como } \\
\text { resíduo das glebas. }\end{array}$ & $\begin{array}{l}\text { Obras de qualificação do } \\
\text { sistema viário intraurbano } \\
\text { (canalizações, viadutos). } \\
\text { Implantação do parque do } \\
\text { Sabiá. }\end{array}$ \\
\hline $\begin{array}{l}1980 a \\
2000\end{array}$ & $\begin{array}{l}\text { Industrialização. } \\
\text { Desenvolvimento } \\
\text { do setor logístico. } \\
\text { Novos conjuntos } \\
\text { habitacionais. } \\
\text { Primeiros centros } \\
\text { comerciais. }\end{array}$ & $\begin{array}{l}\text { Plano Diretor } \\
1994\end{array}$ & $\begin{array}{l}\text { Bairros jardins, } \\
\text { valorizando os } \\
\text { espaços livres. } \\
\text { Descontinuidade } \\
\text { urbana. }\end{array}$ & $\begin{array}{l}\text { Novos bairros para a elite } \\
\text { da cidade, com jardins } \\
\text { frontais. } \\
\text { Loteamentos com praças } \\
\text { e áreas verdes não } \\
\text { implantados. }\end{array}$ \\
\hline $\begin{array}{l}2000 \text { até } \\
\text { os dias } \\
\text { atuais }\end{array}$ & $\begin{array}{l}\text { Crescimento do } \\
\text { setor de serviços. } \\
\text { Intensificação } \\
\text { da implantação } \\
\text { de condomínios } \\
\text { horizontais } \\
\text { reforçando a } \\
\text { segregação } \\
\text { espacial. }\end{array}$ & $\begin{array}{l}\text { Plano Diretor } \\
2006 \\
\text { Lei } \\
\text { n. } 245 / 2000\end{array}$ & $\begin{array}{l}\text { Ocupação de } \\
\text { áreas destinadas } \\
\text { à especulação } \\
\text { imobiliária. } \\
\text { Necessidade } \\
\text { crescente de frear } \\
\text { a expansão urbana } \\
\text { horizontal. }\end{array}$ & $\begin{array}{l}\text { Intensificação da } \\
\text { qualificação do sistema } \\
\text { viário (anel viário, } \\
\text { duplicações de rodovias } \\
\text { em áreas urbanas). } \\
\text { Implantação de um trecho } \\
\text { do Parque Linear Rio } \\
\text { Uberabinha. }\end{array}$ \\
\hline
\end{tabular}

Elaboração: Glauco de Paula Cocozza e Lucas Martins de Oliveira - 2012. 


\section{REFERÊNCIAS BIBLIOGRÁFICAS}

AMORIM FILHO, Oswaldo Bueno; SENA FILHO, Nelson de. A morfologia das cidades médias. Goiânia: Editora Vieira, 2005. $116 \mathrm{p}$.

COCOZZA, Glauco de Paula; OLIVEIRA, Lucas Martins de. Espaços e espacialidades: caracterização dos espaços livres de Uberlândia. In: 5 COLÓQUIO QUAPÁ-SEL, 2010, São Paulo.

; U. Urban form and open spaces: the case of Brazilian medium-sized cities. In: INTERNATIONAL SEMINAR ON URBAN FORM - ISUF, 18, 2011, Montreal. Urban Morphology and the Post-Carbon City, Montreal, 2011.

COCOZZA, Glauco de Paula; OLIVEIRA, Lucas Martins de; LIBERA, Izabela Ilka Medeiros Dalla. O sistema de espaços livres e a constituição da forma urbana na cidade de Uberlândia, MG. In: COLÓQUIO QUAPÁSEL, 6, 2011 , São Paulo. $6^{\circ}$ Colóquio QUAPÁ-SEL. São Paulo, 2011.

FONSECA, Maria de Lourdes Pereira. 2007. 353 f. Forma urbana e uso do espaço público: as transformações no centro de Uberlândia, Brasil. Tese (Doutorado em Urbanismo) - Universidad Politécnica de Cataluña, Barcelona, 2007.

GUERRA, Maria Eliza Alves. As praças modernas de João Jorge Coury no Triângulo Mineiro. 1998. 220 f.

Dissertação (Mestrado em Arquitetura e Urbanismo) - Escola de Engenharia de São Carlos da Universidade de São Paulo, São Carlos, 1998.

PAIVA, Kauê Felipe; CAPPELLO, Maria Beatriz Camargo. Documentação dos projetos para a praça Sérgio Pacheco em Uberlândia: a proposta de Ary Garcia Roza e Roberto Burle Marx. In: Horizonte Científico, v. 5, n. 5, 2011 , Uberlândia, p. 1-35.

UBERLÂNDIA (MG). Câmara Municipal de Uberlândia. Lei complementar n 432 de 19 de outubro de 2006. Aprova o plano diretor do município de Uberlândia, estabelece os princípios básicos e as diretrizes para sua implantação, revoga a Lei Complementar nº 078 de 27 de abril de 1994 e dá outras providências. Disponível em: $<$ http://www.uberlandia.mg.gov.br/?pagina=leisMunicipais >. Acesso em: 30 ago. 2010.

UBERLÂNDIA (MG). Prefeitura Municipal. Secretaria Municipal de Meio Ambiente, 2010. Disponível em: $<$ http://www.uberlandia.mg.gov.br>. Acesso em: 30 ago. 2010. 
